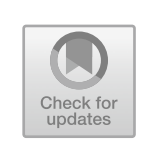

\title{
Safeguarding Democracy and the Rule of Law by Civil Society Actors? The Case of Poland
}

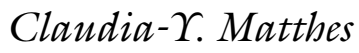

\section{INTRODUCTION}

The judicial reforms which the party Law and Justice (Prawo i Sprawiedliwość, PiS) started directly after being elected into government in November 2015 targeted four institutions: the Constitutional Tribunal (Trybunał Konstytucyjny, TK), the Supreme Court (Sąd Najwyższy, SN), the National Council of the Judiciary (Krajowa Rada Sądownictwa, KRS) and the common courts. While there had already been a debate for years about the workload and efficiency of Polish courts, the content of changes shows that the government's goal was primarily to exert political control on them. Both the $\mathrm{SN}$ and the TK had gained a reputation as independent actors and defenders of civil rights and therefore, according to the government's blueprint to reorganise the state, courts were the first target. In line with these changes, the government re-merged the offices of the attorney general and the minister of justice who received additional powers of discretion. While the European Commission had waited a while until it took some action against similar changes in Hungary, it raised its

\section{C.-Y. Matthes $(\bowtie)$}

Humboldt-Universität zu Berlin, Berlin, Germany

e-mail: claudia.matthes@sowi.hu-berlin.de

(C) The Author(s) 2021

A. Lorenz and L. H. Anders (eds.), Illiberal Trends and Anti-EU Politics

in East Central Europe, Palgrave Studies in European Union Politics, https://doi.org/10.1007/978-3-030-54674-8_11 
voice very quickly in the Polish case and asked the government to rework the legislation.

However, considering the time that has passed since the European Commission launched the Rule of Law Framework and the Article 7 procedure against Poland in January 2016 and December 2017, respectively, and the meagre results that were achieved, these two instruments are generally assessed rather negatively and the EU does not perform well as a normative power in terms of rule of law principles (Ágh 2018; for a similar view regarding Hungary, see Chapters 9 and 10). Explanations reach from party politics and power plays inside the European institutions to the ineffectiveness of the EU's legal measures (Kochenov 2018, p. 4; Pech and Scheppele 2017). There are no legal mechanisms to enforce the values mentioned in Article 2 TEU and no effective means to fine member states that do not comply by the rules out of ideological reasons (Kochenov 2018, p. 10; Mader 2018). In addition, Commission, EP and Council often do not act along similar lines (Oliver and Stefanelli 2016; Bárd and Carrera 2017, pp. 7-9), and the requirement for unanimous voting on the question of if a member state shall lose its voting rights in the Council (plus the two-thirds majority in the Parliament) proves to be too high a hurdle to take a decision (Closa 2019).

Hence, in academia new forms of conditionality, such as a rule of law clause in the multi-annual financial framework (Halmai 2018), and a purely legal approach that trusts in the Court of Justice of the European Union (CJEU), are discussed (Kelemen and Blauberger 2017; De Schutter 2017; Niklewicz 2017, p. 286). Sedelmeier (2017) is one of the few authors who see some potential in the social pressure that the Rule of Law Framework exerts on member states if its formal, transparent and public nature were applied more consistently. A similar process of reflection is currently occurring in the Commission. In April 2019, it asked for responses from stakeholders on how to strengthen the rule of law (European Commission 2019a) and published a communication in July that lays, among other issues, an emphasis on civil society actors (European Commission 2019b, p. 6).

Now, the question is to what extent civil society actors in post-socialist countries are ready for such an active role. On the one hand, literature on the topic is relatively hesitant to assign them the ability to act across the levels of decision-making in the European polity (Kutter and Trappmann 2010). On the other hand, there are civil society actors in Poland that do 
speak out loudly against the decline of the rule of law at numerous antigovernment and pro-EU demonstrations (Mycielski 2016; Bień-Kacała 2017; O’Neal 2017).

The focus of the following chapter is to understand how and to what extent civil society, especially the civil rights movement, can serve as a further hinge for the Commission into a member state society ${ }^{1}$ by articulating its protest on the domestic and the EU level. The next section sets out a theoretical framework for the analysis of civil society operating in the multi-level system of the EU. It is followed by a look into the domestic opportunity structure in which civil society actors operate in Poland and an analysis of their protest repertoire based on these groups' publications, websites and secondary sources. The last section discusses the relevance of the findings for a possible improvement of the procedures to protect the rule of law.

\section{Theoretical Framework-Civil Society and Its Potential for a Watchdog Function}

The involvement of civil society in EU governance and policy-making in general has become a widely investigated topic. Research on the issue can be divided into two strands of literature: one analyses the openness of the EU's institutional setting for NGOs (Heritier 2003; Börzel 2010); the other, the domestic conditions under which NGOs operate and how these allow them to engage in the multi-level-governance game (KohlerKoch and Buth 2011; Pleines 2010). Inside the European Union, the inclusion of civil society has become a topic since the implementation of the Maastricht Treaty in 1992. In order to increase the legitimacy of the $\mathrm{EU}$, so-called soft-modes of governance that include civil society actors into policy-making were discovered as a solution to many of the then existing problems. Accordingly, civil society needs to have some organisational features that facilitate collective action, something that loose social movements or random gatherings of people in public are hardly able to do (Saurugger 2006). As Heidbreder (2012, p. 9) summarises, civil society on the EU level can have three functions: to complement existing modes of decision-making, to help to provide better policy-solutions and to

${ }^{1}$ Considering that PiS received just a relative majority of votes at the elections in 2015 (Fomina and Kucharczyk 2016, p. 62) and 70-80\% of the Polish population is constantly positive about EU-membership (CBOS 2019), see Chapter 1. 
increase the legitimacy of the EU polity. Here, the focus is not on policymaking, but on action against the decline of the rule of law, and both sides, civil society and European institutions, can increase their legitimacy through problem-solving.

Regarding the capacities of NGOs and interest associations in the democracies of Central and Eastern Europe (CEE) previous research showed that legacies of socialist times hinder them to act as watchdog organisations. Kutter and Trappmann (2010) and Pleines (2010) provide quite critical assessments of the ability of interest groups to use the EU system for their needs. According to their findings, legacies understood as social institutions, habits and discourses from the (post-)socialist period, compared with experiences made during the EU accession period and the various stimuli the EU provides to civil society, produce an ambiguous situation: some interest groups were able to adapt to the EU's expertise and bureaucracy-driven style of governance, while others still struggle with a new opportunity structure, an ongoing transformation of domestic state structures, clientelism and politicised bureaucracies. They also lack knowledge about the political process, the EU decision-making structures, language competencies, the ability to network in a multi-level arena and have only limited personnel.

Hence, on the one side, there are very outspoken civil society actors, in Poland and the region (Guasti 2016) that may have an impact. But on the other side, a fruitful EU-NGO relationship in the field of rule of law backsliding may be difficult to achieve. NGOs have to develop specific strategies in order to be able to handle the challenges of the multi-level system of the EU and they have to mediate two, partly contradicting tasks: to be professionalised Brussels-activists on the one side, and to be rooted in their national, regional or local stakeholder context on the other side (Heidbreder 2012, p. 11). Therefore, the idea to include civil society actors in order to achieve better or more legitimate policy outcomes is a normative goal and the realisation of which requires a very pragmatic and professionalised approach by civil society actors.

For the analysis, these reflections are operationalised by taking categories from the study of social movements: The civil society actors address an issue of grievance, the decline of the rule of law, and they have to operate in a domestic and European political opportunity structure (Kriesi et al. 1992) that has an influence on how they shape their protest repertoire and impact. The question is therefore, how the civil society actors respond, and how they are able to mobilise resources (McCarthy and Zald 
1977) in terms of attention, supporters and access to decision-makers. So, under which circumstances did NGOs operate, which strategies or activities did they unfold between 2015 and 2019, and how did they approach the EU and the public?

\section{Civil Society in Poland-Its Shape and Current Political Opportunity Structure}

Civil society in Poland has sometimes been described as weak, but has also been considered as vivid and resistive due to the legacy of Solidarność and civil disobedience practiced in socialist times. After 1989, during the economic transformation, trade unions, despite their tremendous decline in membership, remained an important actor that has frequently organised strikes or demonstrations in the course of privatisation and reconstruction (Ekiert and Kubik 2014, p. 51). The civil rights branch of Solidarność has survived as well, and today, several organisations operate in this field. Next to organised civil society, many less formalised grassroot initiatives and private networks exist (Jacobsson and Korolczuk 2017 , pp. 4-5). The sector is characterised by a certain concentration since four per cent of NGOs account for $80 \%$ of the sector's income, and being engaged in a formalised organisation is an activity mainly conducted by urban, well-educated people. The reason for that being low levels of social trust and lack of resources (Matthes 2016, p. 295).

Rymsza (2016, p. 439) stresses the effects of this for formalisation and organisational advancement of civil society. She highlights the trend that Polish associations lose members and, at the same time, have to look for more professional employees, so they are forced to focus on donors and funding rather than collaborators. In addition, NGOs are struggling to get more positive media coverage and their dependence on close relations to public administration, especially on the local level, creates further obstacles for a more autonomous non-state sector.

Since PiS came to power, these opportunity structures for NGOs have become more restrictive. The government controls the state media, and thus, their reporting on NGOs that do not match the goals of the PiS, such as feminist, LGBT, environmental or human rights groups, is very negative. Smear campaigns in the media aim to create mistrust against the work of NGOs, making donors turn away from them. Then, the government introduced several structural changes that hamper the NGOsector's work. Firstly, it established the Office of the Plenipotentiary for 
Civil Society in early 2016. It was introduced as an institution to facilitate government-society relations and to assist with and channel state funding to the civic sector. Yet, in practice, it rather proved to be a body of control than support (Rymsza 2016, p. 444). Secondly, the hasty mode of lawmaking that PiS is practicing shows that it has no interest in true and intensive consultation with civil society actors, experts or stakeholders. This is possible because bills are often introduced by individual MPs, not the government, which allows to circumvent these hearings (Matthes et al. 2019). Thirdly, assembly rights were restricted because the mode of registering and permitting demonstrations now follows a certain hierarchy and two demonstrations at the same time may be forbidden.

The government also changed to the mode of financing the NGO sector. Since 2016, several cases of stopped or reduced public funding to NGOs were reported for organisations that work on topics such as domestic violence, migration or integration (Szuleka 2018, p. 16). The National Institute of Freedom, established in autumn 2017 with the task of distributing public funds, is another tool to regulate civil society (Matthes et al. 2019, p. 24).

Finally, the political constraints of the court system have implications for NGOs. Since December 2016, the Constitutional Tribunal, through changes of its internal procedures of decision-making and the composition of its judges, is no longer an independent institution. Many courts in Poland do not recognise its rulings, since they claim there would be no legal security, hence it is also no option to seek for domestic protection of the rule of law there. Rather, the minister of justice threatens those judges who do not accept the primacy of the TK (Davies 2018, p. 4; Sadurski 2018b; Czarny 2018). The Supreme Court is still struggling to maintain its independence, since the CJEU declared the governments' attempts to introduce a new retirement age unconstitutional and is now about to deliver a judgement on the introduction of two new chambers, the Disciplinary Chamber and the Public Affairs and Extraordinary Control Chamber ${ }^{2}$ (Buras and Knaus 2018; Sadurski 2018a; ŚledzińskaSimon 2018). All in all, the independence of the judicial system is

\footnotetext{
2 These chambers can decide upon disciplinary measures against judges and reopen cases from the last 20 years. Their members are appointed by the Minister of Justice. The National Council of the Judiciary, responsible for the nomination of judges to fill void seats in any court, is now dominated by judges who are close to the government (Sadurski 2018a).
} 
clearly curtailed, and so far the ruling party adopted only very cosmetic changes of the respective legislation, despite critical reports by the Council of Europe's Venice Commission (Venice Commission 2016a, b, 2017) and the European Commission's Rule of Law Framework. Hence, the ability of civil society actors to operate as watchdog organisations or to contribute to protest actions of social movements has been cut back by legal, structural and financial conditions.

\section{Civil Society's Protest Repertoire-Actions TAKen BetWeEn WarsaW and BRUssels}

After the elections in October 2015, when the plans of the new PiS government to dismantle the rule of law and take control of the state media became more visible, civil society was unprepared at first but quickly became able to speak out in public. Existing watchdog organisations like the Helsinki Foundation for Human Rights (HFHR) or the Stefan Batory Foundation, both already established in 1988/1989, started to monitor the government, and a new movement emerged that gathered the protesters and called for demonstrations, the Committee for the Defence of Democracy (Komitet Obrony Democracij, KOD). ${ }^{3}$ The call for KOD as a movement that would defend democratic values came from the activist and writer Krzysztof Łoziński. An unknown ITspecialist, Mateusz Kijowski, launched a Facebook group in November 2015, which three days after its initiation, already had around 30,000 followers (Eriksson 2016). These different groups, NGOs and KOD, started to engage in several protest activities.

Demonstrations were the first, spontaneous reaction and KOD was very effective in mobilising many people in the larger cities of Warsaw, Craców, Poznań and later elsewhere, also outside Poland. The first large demonstration with 50,000 participants took place in December 2015 and all the following ones were held each time after a new law or action by the government or other relevant incidents occurred or on special dates, such as June 4, to commemorate the first half-free elections from

${ }^{3}$ KOD was named after the Committee for the Defense of Workers (Komitet Obrony Robotników, KOR) which was established in 1976 and advanced the larger Solidarność movement. It had helped imprisoned workers by raising money from Western institutions, providing legal support and organising protest and solidarity events (Karolewski 2016, p. 260). 
1989 and to create a link between the freedom struggles from these years to today's situation. In February 2016, 80-100,000 participants gathered; on March 12, after a visit and report by the Council of Europe's Venice Commission, tens of thousands of people convened, as well as after their next visit in June 2016 with 250,000 participants and again in September. In July 2017, people even demonstrated for around ten days when amendments to the law on the Supreme Court were discussed (Amnesty International 2017).

At the demonstrations, direct references to the EU were made and people held European flags as well as symbols of the Polish Constitution, showing posters in defence of the latter. Nowicka-Franczak (2016, pp. 2-3) distinguished four different types of slogans: (1) liberal and democratic slogans, referring to democratic principles such as rule of law or free media; (2) historical and symbolic slogans that refer back to the opposition movement in socialist times; (3) anti-government slogans; and (4) slogans that have an ironic, pop-cultural connotation and again aim to create a bond with liberal, European values. The PiS-government responded with very polarising language, calling the protesters traitors of the Polish nation and tried to deprive them of their right to protest.

The participants in the demonstrations were somewhat middle-aged and older people with a memory of the previous authoritarian regime. For quite a while younger people were less visible. As election results and surveys show, a certain number of them were rather conservative or unpolitical and not interested in rule of law issues, or more leftist and therefore not attracted by KOD's more centrist approach (Nowicka-Franczak 2016, pp. 3-4). The leftist youngsters rather follow the movement Razem (Together) that was established in 2015 and was, opposite to KOD, more critical of the previous government, which Razem blames for its social policy failures (Pehe 2016).

Spreading information and rising attention about the decline of the rule of law was another means of protest. The civil society groups and the KOD movement issued press statements, used social media for different purposes and published their own judicial analyses on their websites that address the respective changes in each of the courts and show their impact on the work of judges (Szuleka 2018; Amnesty International 2017, 2019; Helsinki Foundation for Human Rights 2019; Batory Foundation 2018). All organisations also issue petitions and open-letters to Polish politicians, MPs in the European Parliament and the European Commission (Fleger 2017). At the peak of the demonstrations against the changes of the 
TK, KOD-spokesperson Mateusz Kijowski gave plenty of interviews to many foreign newspapers in order to make this issue known to the world (Karolewski 2016, p. 260).

The tool of strategic litigation and the provision of pro bono legal support had been especially used by lawyers in the field of human rights in previous years, e.g. by the HFHR. Their strategic litigation programme has operated since 2004 and joins or initiates court cases that are of strategic importance to obtain fundamental judgements that can make a change in the field of human rights. Since 2015, this practice has become less relevant in Poland because of the political control of courts. However, HFHR is very active in referring cases and asking for preliminary judgements by the CJEU; several Polish lawyers are actively defending judicial personnel against accusations by politicians in Polish and European courts and they submit complaints to the relevant bodies of the UN (Helsinki Foundation for Human Rights 2018).

All these activist groups operated very internationally from the very beginning, although their framing of the situation aimed to highlight the similarities to the struggle against the communist regime back in the 1970s and 1980s (Fleger 2017, p. 13). They actively sought contact with the European Commission and the European Parliament. In January 2016, KOD had already met with the European Green Party to discuss the development in Poland. Shortly after, it published a letter to the European Parliament on its website and met with representatives of the Greens and the Liberals in the EP (Karolewski 2016, p. 263). When KOD received the European Parliament's European Citizen's Prize in June 2016, this was an occasion to meet with several notable individuals: Frans Timmermans, then First Vice-President and European Commissioner for Better Regulation, Interinstitutional Relations, the Rule of Law and the Charter of Fundamental Rights; Martin Schulz, then-President of the EP, and Donald Tusk as then-Representative of the Council. Finally, KOD opened a representation with an office in Brussels. In 2017, several other civil society actors sent an open letter to the Commission (Fleger 2017, p. 8) and human rights groups continued to lobby the Commission. They supported the idea to launch the rule of law procedure in January 2016 as well as the Article 7 procedure in December 2017 (Open Letter 2017). Several Polish and international NGOs met with Frans Timmermans and/or his aides on several occasions between 2016 and 2019 and discussed rule of law issues. 
The collaboration between KOD and political parties inside Poland is somewhat ambivalent. On the one side, KOD was the main organiser of the demonstrations, at which opposition politicians, especially from the Civic Platform (Platforma Obywatelska, PO), the .Modern (.Nowoczesna), as well as from Polish People's Party (Polskie Stronnictwo Ludowe, PSL) also participated. On the other side, it was not always clear where to draw the line between movement and parties. There was some debate if KOD should turn into a political party, or become part of PO or .Nowoczesna. Critiques of the movement were arguing that KOD was simply the prolonged, extra-parliamentary arm of the political opposition that used the streets to exert pressure on the government or where previous politicians were able to get some new attention (Karolewski 2016, p. 260, Nowicka-Franczak 2016, p. 5). On May 10, 2016, KOD, PSL, .Nowoczesna and leftist parties outside parliament formed the coalition "Freedom, Equality, Democracy", while PO did not join the network.

Considering these debates and the increased restrictions for civil society inside Poland, networking within the civic sector became more important. On June 4, 2018, first eight, then 12 organisations agreed to form a common platform, the Justice Defense Committee (Komitet Obrony Sprawiedliwości, KOS). They chose June 4 as a founding date to refer to the day when the first half-free elections in Poland had taken place in 1989. Their common aim is to protect judges, prosecutors and other legal professionals when they come under political pressure by reporting about such cases to the wider public, presenting opinions, holding press conferences and by providing legal support for them. KOS also sends letters to relevant Polish politicians and EU institutions (KOS 2019). This has become especially important, according to KOS, after the introduction of the new disciplinary chamber in the Supreme Court, and the new Law on the Ordinary Courts from April 3,2018 that introduced a system of disciplinary liability of judges. In addition, the media, which is close to the government, came up with invented stories that aimed to discredit the reputation of judges in general or some judges as persons, including the billboard campaign "Just courts" (KOS 2018, p. 20).

KOS consists of associations of five legal professionals (Themis, Iustitia, LEX Super Omnia, Forum Współpracy Sędziów, Ogólnopolskie Stowarzyszenie Sędziów Sądów), three civil rights organisations (Helsinki Foundation for Human Rights, Amnesty International Poland, Forum Obywatelskiego Rozwoju), a think tank (INPRIS), two archives of legal 
scholars that also consider themselves as actors having to secure the rule of law (Stowarzyszenie im. Prof. Zbigniew Hołdy and Archiwum Osiatyńskiego) and an activist movement of four lawyers, Wolny Sacdy (Free Courts), that caught the public's attention through small films they post online showing the importance of free courts (https://de-de. facebook.com/WolneSady/). Convening KOS was also a reaction to the decline of KOD after its founder Kijowski faced some quarrels due to paying himself out of KOD's budget, billing it for computer services. Later, he stepped down as a chairperson (Cienski 2017); KOD lost some momentum but is still active in and outside of Poland (http://www.ruc hkod.pl/).

\section{Impact and Resonance of the Civic Activities}

The existence of the protest movement did mobilise Polish society since plenty of people attend the demonstrations and support KOD's and other organisations' actions. According to a poll by TNS, 1.5 million (or 5\%) of Poles took part in at least one protest event organised by KOD. $40 \%$ said they would support the movement, while $28 \%$ were against it and the rest had never heard of it (Eriksson 2016). Despite the restrictions in terms of personnel, money and capacities the associations are actually quite successful in their access to the public and do receive a lot of attention. Firstly, one of the reasons for their ability to overcome the structural restrictions was their intensive use of social media that helped them to disseminate their messages more easily and to react to the framing of a topic in the public sphere by the Polish government. Since it uses different types of public media and poster campaigns to spread negative messages about NGOs with the intention to produce a rally around the flag effect (Schlipphak and Treib 2017), communication against these defaming messages was relevant.

Secondly, the civil society actors built networks with different domestic NGOs that can reach out to different segments of society and therefore produce a certain snowball effect regarding public attention. This networking enables the associations and movements to meet the challenge of being locally rooted and having networking-knowhow about the EU polity in an efficient way. Plus, NGOs based in Poland, such as the Stefan Batory Foundation that have access to European funding and networks, provide knowhow inside the country as well as material support for publications and maintenance of websites. Civil society actors also managed to 
make use of broader networks, such as Civil Society Europe, or globally operating NGOs like Amnesty International.

This networking helped the Polish NGOs to become more known in Brussels, so that they were invited to hearings at the CJEU, meetings with Commissioner Frans Timmermans and the committees of the European Parliament, especially the LIBE committee that deals with rule of law issues. The NGO networks also use the Commission's representation in Warsaw as a shortcut to Brussels; they provide information, assessments on the legal situation and evidence about disciplinary procedures against judges and prosecutors.

Although the Polish government made only very few changes to the legislation on the court system, the actions of the civil society were not at all useless, neither in formal terms, regarding the material policies, nor in an informal way, regarding the mobilisation of the domestic public and the European decision-makers. The decision of the Commission to launch the infringement procedures, as well as the Article 7 procedure, can also be considered as successful agenda-setting of the Polish NGOs that were able to upload their demands into EU structures. Meetings with Commission representatives working around Mr. Timmermans will have at least reinforced the intention of the Commission to push forward with the respective measures.

Opposite to the more sceptical findings in the majority of the literature, following Wunsch (2016) and her analysis of Croatian NGOs, the Polish human rights groups are also not necessarily marginalised actors but could navigate strategically inside the EU's multi-level system. Now, it is the task of the new Commission, elected in autumn 2019, to continue the procedure.

However, despite these achievements, and although KOD claims to be politically neutral, it is a movement of urban, liberal-minded and politically centrist people. Some leftist politicians did participate because they felt the urge to speak out against the changes of the court system, but others did not. Hence, a considerable amount of working class people, or people who had not yet profited sufficiently from the system change since 1989, felt attracted by PiS's generous social policy, something that the previous PO and PSL government had neglected. So, while the collaboration between the liberal parts of civil society and the European institutions seems to be a fruitful tool in order to address and tackle the decline of the rule of law, there is an important message to learn: the European institutions should not only close ranks with like-minded NGOs, but should see 
and address the society of a member state as a whole, in all its political facets and social needs and political attention; in addition, financial and other support should not only concentrate on one group of people.

\section{Conclusion}

The chapter explored the question if NGOs have the capacity to lobby EU institutions in order to uphold pressure on the Polish government and if they are strong enough to act as one of the counterforces against the decline of the rule of law. The expectation was that, considering the structural difficulties for civil society organisations to engage in the multi-level system of the EU, they may need to develop specific strategies to compensate for the challenges of this task, especially since the domestic opportunity structure for NGOs became even tighter due to the constraints implemented by the current government in the judicial and media sector. This means that the changes of the judiciary against which the NGOs act, at the same time, affect the opportunity structure in which they operate. The results found so far confirm the difficulties that NGOs have to struggle with, but also show that civil society gained quite some agency. By networking among each other and an early and intensive reach out not only to the national but also to the European level, along with the usage of social media and the collaboration with NGOs that already have a European network and can open access to the Commission, they were able to overcome shortcomings in national resources and opportunity structures.

The analysis also shows that social pressure from national interest associations is important to lift and to keep a topic on the European agenda. While it is a challenge for the Commission to find a working tool against a non-complying government when political majorities allow to simply ignore the "blaming and shaming", civil society actors can serve as an alternative to political opposition parties inside member states as the Commission wants to stay impartial politically. Although only legal pressure through infringement procedures has stopped democratic backsliding on some occasions, and also in Poland, it is nevertheless crucial to engage with and invest in civil society associations that support and defend European values because they can generate and provide information, attention and support. 


\section{REFERENCES}

Ágh, Attila. 2018. Decline of Democracy in the ECE and the Core-Periphery Divide: Rule of Law Conflicts of Poland and Hungary with the EU. Journal of Comparative Politics 11 (2): 30-48.

Amnesty International. 2017. Poland: On the Streets to Defend Human Rights: Harassment, Surveillance and Prosecution of Protesters. https://www.amnesty. ie/poland-streets-defend-human-rights/. Accessed 8 August 2019.

Amnesty International. 2019. Poland: The Judges Who Defend the Rule of Law, London. https://www.amnesty.org/en/documents/eur37/9800/2019/en/. Accessed 8 August 2019.

Bárd, Petra, and Sergio Carrera. 2017. The Commission's Decision on 'Less EU' in Safeguarding the Rule of Law: A Play in Four Acts, 8. No: CEPS Policy Insights.

Batory Foundation. 2018. Position of the Stefan Batory Foundation Legal Expert Group on the Amendment to the Law on the Supreme Court Adopted on 21 November 2018. http://www.batory.org.pl/upload/Stanowisko_ZEP_26.11_ eng.pdf. Accessed 15 October 2019.

Bien-Kacała, Agnieszka. 2017. Poland within the EU-Dealing with the Populist Agenda. Osteuropa Recht 63 (4): 428-443.

Börzel, Tanja. 2010. Why You Don't Always Get What You Want: EU Enlargement and Civil Society in Central and Eastern Europe. Acta Politica 45: $1-10$.

Buras, Piotr, and Gerald Knaus. 2018. Where the Law Ends: The Collapse of the Rule of Law in Poland-And What to Do. Batory Foundation, European Stability Initiative. https://www.esiweb.org/index.php?lang=en\& id=156\&document_ID=190. Accessed 10 August 2019.

CBOS. 2019. Fifteen Years of Poland's Membership in the European Union. Komunikat z Badań Nr 59. Warsaw: Fundacja Centrum Badania Opinii Społecznej.

Cienski, Jan. 2017. Polish Opposition Leader Hit by Cash Conflict. Mateusz Kijowski Is the Most-Visible Challenger to PiS Government in Rule of Law Debate. Politico, January 5. https://www.politico.eu/article/mateusz-kij owski-kod-polish-opposition-leader-hit-by-cash-conflict/. Accessed 4 March 2020.

Closa, Carlos. 2019. The Politics of Guarding the Treaties: Commission Scrutiny of Rule of Law Compliance. Journal of European Public Policy 26 (5): 696716.

Czarny, Piotr. 2018. Der Streit um den Verfassungsgerichtshof in Polen 20152016. Osteuropa Recht 64 (19): 5-20.

Davies, Christian. 2018. Hostile Takeover: How Law and Justice Captured Poland's Courts, In Nations in Transit Brief. Freedom House. https://fre 
edomhouse.org/report/special-reports/hostile-takeover-how-law-and-justicecaptured-poland-s-courts. Accessed 15 September 2019.

De Schutter, Olivier. 2017. Infringement Proceedings as a Tool for the Enforcement of fundamental Rights in the European Union. Brussels: Open Society European Policy Institute.

Ekiert, Grzegorz, and Jan Kubik. 2014. The Legacies of 1989: Myths and Realities of Civil Society. Journal of Democracy 25 (1): 46-58.

Eriksson, Aleksandra. 2016. What Is KOD, the Polish Pro-democracy Movement? EUObserver, June 4. https://euobserver.com/political/133698. Accessed 12 September 2019.

European Commission. 2019a. Further Strengthening the Rule of Law within the Union. State of Play and Possible Next Steps. Communication from the Commission to the European Parliament, the European Council and the Council. COM/2019/163 final. Brussels.

European Commission. 2019b. Strengthening the Rule of Law Within the Union. A Blueprint for Action. Communication from the Commission to the European Parliament, the European Council, the Council, the European Economic and Social Committee and the Committee of the Regions. COM/2019/343 final. Brussels.

Fleger, Johanna. 2017. Regime Change and Public Protest in Poland: Comparing Past and Present. Democracy and Resentment 3. https://openjournals.maastr ichtuniversity.nl/Marble/article/view/544. https://doi.org/10.26481/mar ble.2017.v3.544.

Fomina, Joanna, and Jacek Kucharczyk. 2016. The Specter Haunting Europe: Populism and Protest in Poland. Journal of Democracy 27 (4): 58-68.

Guasti, Petra. 2016. Development of Citizen Participation in Central and Eastern Europe After the EU Enlargement and Economic Crises. Communist and Post-Communist Studies 49 (3): 219-231.

Halmai, Gabór. 2018. The Possibility and Desirability of Rule of Law Conditionality. The Hague Journal of Rule of Law. https://doi.org/10.1007/s40 803-018-0077-2.

Heidbreder, Eva G. 2012. Civil Society Participation in EU Governance. Living Reviews in European Governance 7 (2): 1-42.

Helsinki Foundation for Human Rights. 2018. Human Rights in Strategic Litigation 2018 Report. http://www.hfhr.pl/en/publication/human-rights-in-str ategic-litigation-2018-report/. Accessed 27 September 2019.

Helsinki Foundation for Human Rights. 2019. Disciplinary Proceedings Against Judges and Prosecutors. http://www.hfhr.pl/en/publication/disciplinary-pro ceedings-against-judges-and-prosecutors/. Accessed 25 September 2019.

Heritier, Adrienne. 2003. New Modes of Governance in Europe: Increasing Political Capacity and Policy Effectiveness. In The State of the European Union, 
ed. T. Börzel and R.A. Cichowski, 105-126. Oxford and New York: Oxford University Press.

Jacobsson, Kerstin, and Elzbieta Korolczuk. 2017. Introduction: Rethinking Polish Civil Society. In Civil Society Revisited, Lessons from Poland, ed. K. Jacobsson and E. Korolczuk, 1-35. New York and Oxford: Berghahn Books. Karolewski, Ireneusz P. 2016. Protest and Participation in Post-transformation Poland: The Case of the Committee of the Defense of Democracy (KOD). Communist and Post-Communist Studies 49 (3): 255-267.

Kelemen, R. Daniel, and Michael Blauberger. 2017. Introducing the Debate: European Union Safeguards Against Member States' Democratic Backsliding. Journal of European Public Policy 24 (3): 317-320.

Kochenov, Dimitry. 2018. The EU and the Rule of Law-Naïveté or a Grand Design? University of Groningen Faculty of Law Research Paper Series No. 5 .

Kohler-Koch, Beate, and Vanessa Buth. 2011. Civil Society in EU GovernanceLobby Groups Like Any Other? TranState Working Papers Nr. 108. University of Bremen.

KOS [Komitet Obrony Sprawiedliwości]. 2018. A Country That Punishes. Pressure and Repression of Polish Judges and Prosecutors. Warsaw. http://citize nsobservatory.pl/ustawa/a-country-that-punishes-pressure-and-repression-ofpolish-judges-and-prosecutors-report-by-the-justice-defence-committee-kos /. Accessed 22 June 2019.

KOS [Komitet Obrony Sprawiedliwości]. 2019. https://komitetobronysprawied liwosci.pl/. Accessed 10 December 2019.

Kriesi, Hanspeter, Ruud Koopmans, Jan Willem Duyvendak, and Marco G. Giugni. 1992. New Social Movements and Political Opportunities in Western Europe. European Journal of Political Research 22: 219-244.

Kutter, Amelie, and Vera Trappmann. 2010. Civil Society in Central and Eastern Europe: The Ambivalent Legacy of Accession. Acta Politica 45: 41-69.

Mader, Oliver. 2018. Enforcement of EU Values as a Political Endeavour: Constitutional Pluralism and Value Homogeneity in Times of Persistent Challenges to the Rule of Law. Hague Journal on the Rule of Law. https://doi.org/10. $1007 /$ s40803-018-00083-x.

Matthes, Claudia-Yvette. 2016. The State of Democracy in Poland After 2007. Problems of Post-Communism 63 (5-6): 288-299.

Matthes, Claudia-Yvette, Radoslaw Markowski, and Frank Bönker. 2019. Sustainable Governance Indicators 2019, Poland Report. Bertelsmann-Stiftung. http://www.sgi-network.org/2019/Downloads. Accessed 13 December 2019.

McCarthy, John D., and Mayer N. Zald. 1977. Resource Mobilization and Social Movements: A Partial Theory. American Journal of Sociology 82 (6): 12121241. 
Mycielski, Martin. 2016. The Crisis of European Identity and Awakening of Civil Society. European View 15: 223-232.

Niklewicz, Konrad. 2017. Safeguarding the Rule of Law Within the EU: Lessons from the Polish Experience. European View 16: 281-291.

Nowicka-Franczak, Magdalena. 2016. Committee for the Defense of Democracy in Poland: Rebellion of the "Beneficiaries of the Transformation"? Transit Online. https://www.iwm.at/transit-online/committee-for-the-defense-ofdemocracy-in-poland-rebellion-of-the-beneficiaries-of-the-transformation/\#_ ftn2. Accessed 15 November 2019.

O'Neal, Molly. 2017. The European 'Other' in Poland's Conservative Identity Project. The International Spectator 52 (1): 28-45.

Oliver, Peter, and Justine Stefanelli. 2016. Strengthening the Rule of Law in the EU: The Council's Inaction. Journal of Common Market Studies 54 (5): $1075-1084$.

Open Letter to the College of Commissioners regarding the situation in Poland. 2017, February 16. https://rsf.org/sites/default/files/joint_ngo_ letter_to_the_european_commission_on_poland_28.02.2017.pdf. Accessed 4 March 2020.

Pech, Laurent, and Kim Lane Scheppele. 2017. Illiberalism Within: Rule of Law Backsliding in the EU. Cambridge Yearbook of European Legal Studies 19: 3-47.

Pehe, Veronika. 2016. Razem: The Left in Poland is starting from scratch, May 16. http://politicalcritique.org/cee/poland/2016/razem-the-left-in-polandis-starting-from-scratch-interview/. Accessed 12 November 2019.

Pleines, Heiko. 2010. Is This the Way to Brussels? CEE Civil Society Involvement in EU Governance. Acta Politica 45: 229-246.

Rymsza, Agnieskza. 2016. Main Challenges and Opportunities Faced by the Nonprofit Sector in Current Poland. Society. Integration. Education 4: $434-447$.

Sadurski, Wojciech. 2018a. Polish Constitutional Tribunal Under PiS: From an Activist Court, to a Paralysed Tribunal, to a Governmental Enabler. The Hague Journal of Rule of Law. https://doi.org/10.1007/s40803-0180078-1.

Sadurski, Wojciech. 2018b. How Democracy Dies (in Poland): A Case Study of Anti-Constitutional Populist Backsliding. Sydney Law School, Legal Studies Research Paper No. 18. Sydney.

Saurugger, Sabine. 2006. The Professionalisation of Interest Representation: A Legitimacy Problem for Civil Society in the EU? In Civil Society and Legitimate European Governance, ed. Stijn Smismans, 260-276. Cheltenham and Northampton: Edward Elgar. 
Schlipphak, Bernd, and Oliver Treib. 2017. Playing the Blame Game on Brussels: The Domestic Political Effects of EU Interventions Against Democratic Backsliding. Journal of European Public Policy 24 (3): 352-365.

Sedelmeier, Ulrich. 2017. Political Safeguards Against Democratic Backsliding in the EU: The Limits of Material Sanctions and the Scope of Social Pressure. Journal of European Public Policy 24 (3): 337-351.

Śledzińska-Simon, Anna. 2018. The Rise and Fall of Judicial Self-Government in Poland: On Judicial Reform Reversing Democratic Transition. German Law Journal 19 (7): 1839-1870.

Szuleka, Małgorzata. 2018. First Victims or Last Guardians? The Consequences of Rule of Law Backsliding for NGOs: Case Studies of Hungary and Poland. CEPS Paper in Liberty and Security in Europe No. 06.

Venice Commission. 2016a. Opinion on Amendments to the Act of 25 June 2015 on the Constitutional Tribunal of Poland, Adopted by the Venice Commission at its 108th Plenary Session (Venice, 14-15 October 2016), Opinion 860/2016.

Venice Commission. 2016b. Poland. Opinion on the Act on the Constitutional Tribunal of Poland, Adopted by the Venice Commission at its 106th Plenary Session (Venice, 11-12 March 2016), Opinion no. 833/2015.

Venice Commission. 2017. On the Draft Act Amending the Act on the National Council of the Judiciary, on the Draft Act Amending the Act on the Supreme Court, Proposed by the President of Poland, and on the Act on the Organisation of Ordinary Courts, Adopted by the Venice Commission at Its 113th Plenary Session (8-9 December 2017), Opinion No. 904/.

Wunsch, Natasha. 2016. Coming Full Circle? Differential Empowerment in Croatia's EU Accession Process. Journal of European Public Policy 23 (8): 1199-1217. 
Open Access This chapter is licensed under the terms of the Creative Commons Attribution 4.0 International License (http://creativecommons.org/licenses/ by $/ 4.0 /$ ), which permits use, sharing, adaptation, distribution and reproduction in any medium or format, as long as you give appropriate credit to the original author(s) and the source, provide a link to the Creative Commons license and indicate if changes were made.

The images or other third party material in this chapter are included in the chapter's Creative Commons license, unless indicated otherwise in a credit line to the material. If material is not included in the chapter's Creative Commons license and your intended use is not permitted by statutory regulation or exceeds the permitted use, you will need to obtain permission directly from the copyright holder.

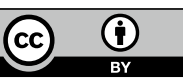

